\title{
Recovery of nitrogen and water from landfill leachate by a microbial electrolysis cell-forward osmosis system
}

\author{
Mohan Qin ${ }^{\mathrm{a}}$, Hannah Molitor ${ }^{\mathrm{b}}$, Brian Brazil ${ }^{\mathrm{c}}$, John T. Novak ${ }^{\mathrm{a}}$, Zhen $\mathrm{He}^{\mathrm{a}, *}$ \\ a Department of Civil and Environmental Engineering, Virginia Polytechnic Institute and State University, Blacksburg, VA 24061, United States \\ ${ }^{\mathrm{b}}$ Department of Civil and Environmental Engineering, University of Wisconsin-Platteville, Platteville, WI 53818, United States

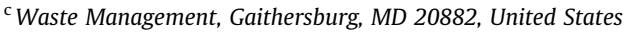

\section{H I G H L I G H T S}

- Ammonia can be successfully recovered from landfill leachate by MECs.

- Recovered ammonia can act as a draw solute in forward osmosis for water recovery.

- Aeration is important to drive ammonia off the catholyte.

- Organic degradation in leachate remains as a great challenge.

\section{A R T I C L E I N F O}

\section{Article history:}

Received 20 September 2015

Received in revised form 16 October 2015

Accepted 17 October 2015

Available online 23 October 2015

\section{Keywords:}

Landfill leachate

Microbial electrolysis cells

Forward osmosis

Ammonium recovery

Ammonium bicarbonate
G R A P H I C A L A B S T R A C T

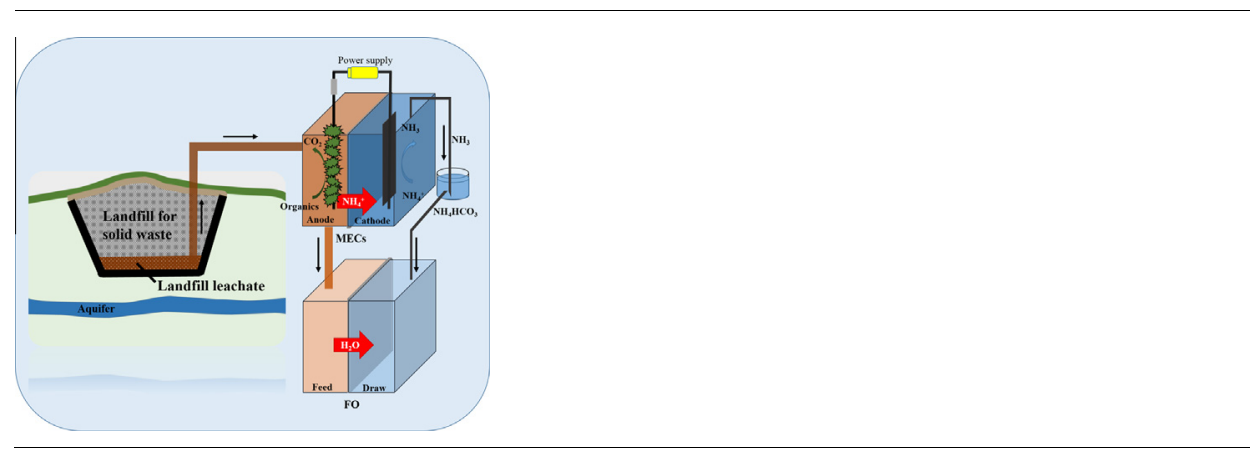

\begin{abstract}
A B S T R A C T
A microbial electrolysis cell (MEC)-forward osmosis (FO) system was previously reported for recovering ammonium and water from synthetic solutions, and here it has been advanced with treating landfill leachate. In the MEC, $65.7 \pm 9.1 \%$ of ammonium could be recovered in the presence of cathode aeration. Without aeration, the MEC could remove $54.1 \pm 10.9 \%$ of ammonium from the leachate, but little ammonia was recovered. With $2 \mathrm{M} \mathrm{NH}_{4} \mathrm{HCO}_{3}$ as the draw solution, the $\mathrm{FO}$ process achieved $51 \%$ water recovery from the MEC anode effluent in 3.5-h operation, higher than that from the raw leachate. The recovered ammonia was used as a draw solute in the FO for successful water recovery from the treated leachate. Despite the challenges with treating returning solution from the FO, this MEC-FO system has demonstrated the potential for resource recovery from wastes, and provide a new solution for sustainable leachate management.
\end{abstract}

(C) 2015 Elsevier Ltd. All rights reserved.

\section{Introduction}

The amount of solid waste is increasing globally because of increased population and living standards, and thus proper treatment of solid waste is critically important to societal development (Hoornweg and Bhada-Tata, 2012). Among waste management options, landfilling is considered as a simple and cost-effective treatment method and often acts as the last destination for the

\footnotetext{
* Corresponding author. Tel.: +1 (540) 231 1346; fax: +1 (540) 2317916 .

E-mail address: zhenhe@vt.edu (Z. He).
}

wastes after appropriate treatment (Renou et al., 2008). Landfill leachate, the liquid waste that drains from the landfill, is produced through decomposition of landfill materials and drainage of precipitation that permeates and percolates through the landfill. Landfill leachate is one of the most complex waste streams to manage because it contains a wide range of organic and inorganic compounds including nutrients, chlorinated organics, inorganic salts and heavy metals (Foo and Hameed, 2009). Leachate characteristics depend on many factors such as waste composition, landfill age, precipitation, and seasonal weather (Kulikowska and Klimiuk, 2008; Puig et al., 2011). The presence of toxic compounds 
in leachate generates problems in both direct disposal to natural water bodies and infiltration into groundwater. Therefore, there is a demand for environmentally sustainable solutions for landfill leachate treatment.

Leachate treatment technologies such as advanced oxidation, membrane separation, chemical treatment, and biological processes have been practiced (Greenman et al., 2009). Especially, biological treatment is widely and effectively employed to remove organic matter and nitrogen from leachate (Gotvajn et al., 2009; Kurniawan et al., 2006). However, leachate usually has a low carbon/nitrogen ratio, which makes the conventional nitrification and denitrification difficult (Puig et al., 2011). Anaerobic ammonium oxidation (anammox) could provide a more sustainable solution for ammonium removal with a high ammonium concentration (Liang and Liu, 2008). Young landfill leachate contains relatively large amounts of biodegradable organic matter which could be aerobically oxidized, involving both energy consumption and the production of sludge. Removal of organic matter could avoid the negative effects on the anammox process (Ruscalleda et al., 2008). To achieve improved quality of the final effluent, membrane processes, such as microfiltration (MF), ultrafiltration (UF), reverse osmosis (RO), and forward osmosis (FO), are also applied in landfill leachate treatment (Cath et al., 2006; Renou et al., 2008). The major drawback of the implementation of membrane process is membrane fouling. Thus, pretreatment of landfill leachate to remove organic matter and to reduce solution conductivity, is required for the membrane process treatment.

Bioelectrochemical systems (BESs) are also studied for simultaneous landfill leachate treatment and energy generation (Damiano et al., 2014; Gálvez et al., 2009; Pant et al., 2010). In BES, such as microbial fuel cells (MFCs) and microbial electrolysis cells (MECs), the organics are oxidized by microorganisms in the anode, and the generated electrons may be used to produce electricity or other valuable chemicals (Wang and Ren, 2013). Because of the high conductivity, high buffering capacity, and high ammonium concentration, landfill leachate is considered as a potential substrate for BES (Mahmoud et al., 2014), especially for MECs, which can remove/ recover ammonium during electricity generation. In MECs, a higher current density could greatly enhance ammonia recovery, and thus MECs with an external power exhibit a better performance for ammonia removal/recovery than MFCs (Zhang et al., 2014). Previous studies of leachate treatment by BES focused on the reduction of chemical oxygen demand (COD) in leachate by various types of MFCs (Ganesh and Jambeck, 2013; Greenman et al., 2009). It was demonstrated that MFCs could generate electricity from leachate, but the excessive organic residues may decrease Coulombic efficiency (CE), especially in membraneless MFC systems (Wu et al., 2015). It was reported that increasing proportions of butyrate and propionate could decrease power density and CE from 1.9 to $1.0 \mathrm{~W} \mathrm{~m}^{-3}$ and from $34 \%$ to $20 \%$, respectively (Teng et al., 2010). Although BES could effective remove organic contaminants in leachate with electricity generation, the study of nutrient removal is very limited. Previous studies showed that $50-70 \%$ of the total nitrogen could be removed from landfill leachate with a dualcathode MFC (Zhang and He, 2013). There have not been any studies that attempted to recover ammonium from leachate in BES.

To explore the potential of resource recovery from landfill leachate, a previously developed MEC-Forward Osmosis (FO) system was adopted here for treating leachate samples. This MEC-FO system was developed to use MECs to recover ammonium from wastewater and use the recovered ammonium as a draw solute in FO for water recovery (Qin and He, 2014). This study moved beyond the previous one with examining the waste (leachate) and the effects of aeration. The specific objectives of this study were to: (1) investigate the ammonium recovery from landfill leachate in an MEC; (2) examine the influence of aeration in the MEC cathode on leachate treatment; and (3) explore the synergistic effect of MEC and FO on resource recovery from leachate.

\section{Methods}

\subsection{The MEC-FO system}

The MEC-FO system consisted of two units, an MEC and an FO, as shown in Fig. 1. The operating procedure: the landfill leachate is fed into the anode chamber of the MEC, and its effluent then flows into the feed side of the FO; the collected ammonia gas from the MEC cathode is used to prepare an ammonium bicarbonate solution with external $\mathrm{CO}_{2}$, which is then used as the draw solution in the FO; and after water extraction in the FO, the concentrated feed solution is returned to the MEC for further treatment.

\subsubsection{MEC setup and operation}

The MEC had a tubular configuration, with a cation exchange membrane (CEM) tube (Membrane International Inc., Ringwood, NJ, USA) to separate the anode and the cathode. The membrane tube was installed in a glass tube, thereby creating two compartments: the cathode (inside the membrane tube) and the anode (between the membrane and the glass tube). The liquid volume of the anode compartment was $500 \mathrm{~mL}$ and the cathode compartment contained $500 \mathrm{~mL}$ deionized water. A 1-m long carbon brush was folded to fit into the anode compartment as the anode electrode. The cathode electrode was a piece of carbon cloth $\left(160 \mathrm{~cm}^{2}\right)$ coated with platinum/carbon as a catalyst (0.3 $\mathrm{mg} \mathrm{Pt} \mathrm{cm}^{-2}$ ) (Zhang et al., 2010). The anode compartment was inoculated with anaerobic sludge collected from the Peppers Ferry Regional Wastewater Treatment Plant (Radford, VA, USA). An external voltage of $0.8 \mathrm{~V}$ was applied to the circuit by a power supply (CSI3644A, Circuit Specialists, Inc., Mesa, AZ, USA) according to a previous study (Yossan et al., 2013). The external resistance was fixed at $1 \Omega$ for high current generation. The MEC was operated in a batch mode at room temperature of $\sim 20^{\circ} \mathrm{C}$. Half of the MEC anolyte (landfill leachate) was replaced every $144 \mathrm{~h}$ or $168 \mathrm{~h}$ depending on the hydraulic retention time (HRT) while the catholyte (DI water) remained unchanged. The MEC cathode was operated with either aeration (oxygen reduction) or no aeration (hydrogen evolution). The HRT was 6 days in the MEC with aeration and 7 days in the MEC without aeration. The difference in HRT in these two modes was due to the different cathode reactions, and the HRT was set based on the maximum COD removal and current generation. At the beginning of each operation mode, the anolyte and the catholyte were disposed and the MEC received fresh leachate as the anolyte and DI water as the catholyte to start new batch cycles. When aeration was supplied, the air was pumped into the cathode compartment at a rate of $95 \mathrm{~mL} \mathrm{~min}^{-1}$ and the waste air was channeled through two 200-mL glass bottles. The first bottle was an absorption bottle, filled with DI water to collect gaseous ammonia $\left(\mathrm{NH}_{3}\right)$ and carbon dioxide $\left(\mathrm{CO}_{2}\right)$ to generate ammonium bicarbonate draw solute. Additional carbon dioxide was introduced into this bottle at a flow rate of $1.02 \mathrm{~mL} \mathrm{~min}^{-1}$ by a $\mathrm{CO}_{2}$ cylinder. The second bottle was filled with $1 \mathrm{M}$ sulfuric acid $\left(\mathrm{H}_{2} \mathrm{SO}_{4}\right)$ to absorb excess $\mathrm{NH}_{3}$ that was not captured by the first bottle, named "recovery bottle". For the MEC without aeration, a gas bag was used to collect the ammonia gas from the cathode compartment.

\subsubsection{FO setup and operation}

A SEPA CF Cell (Sterlitech Corporation, Kent, WA, USA) was used as an FO cell. The FO membrane was cellulose triacetate (Hydration Technology Innovations, Albany, OR) and was installed in the FO cell with its active layer toward the feed solution. During 


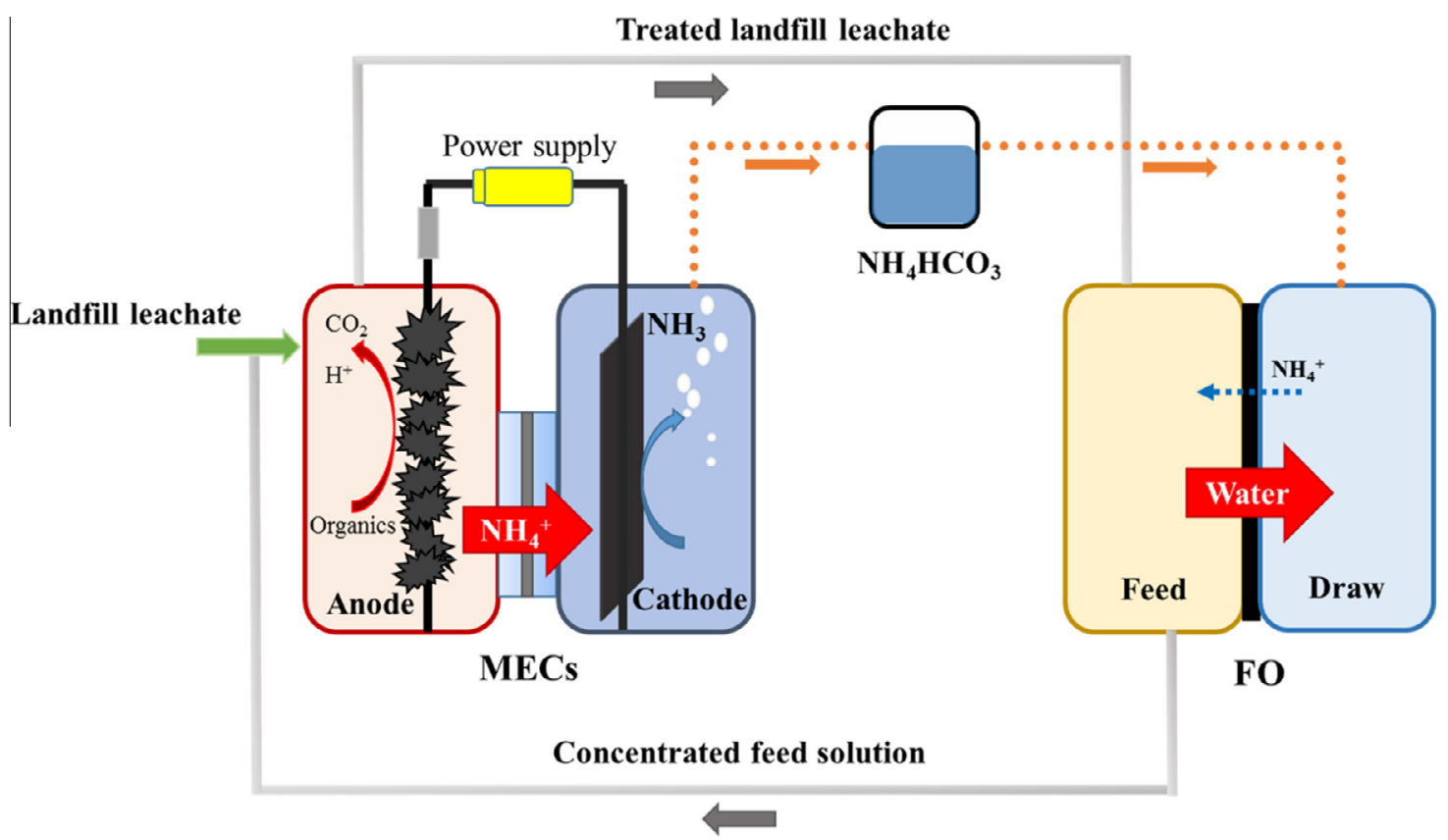

Fig. 1. Schematic of the MEC-FO system.

operation, both the feed solution (treated landfill leachate) and the draw solution (ammonium bicarbonate) were recirculated at $125 \mathrm{~mL} \mathrm{~min}^{-1}$. The water flux $\left(\mathrm{L} \mathrm{m}^{-2} \mathrm{~h}^{-1}, \mathrm{LMH}\right)$ was calculated by the change of weight of the feed or draw solution (Wang et al., 2010). The reverse salt flux $\left(\mathrm{g} \mathrm{m}^{-2} \mathrm{~h}^{-1}\right.$, gMH) from the draw side to the feed side was calculated by measuring the salt concentration change in the feed solution (Wang et al., 2010).

\subsection{Landfill leachate}

Landfill leachate was collected from a landfill site (Waverly, VA, USA) and kept at $4{ }^{\circ} \mathrm{C}$ prior to use. The leachate was used as collected for all experiments without $\mathrm{pH}$ adjustments, addition of nutrients/trace metals, or dilution. The characterization of the landfill leachate is summarized in Table 1 . The landfill leachate contained a high COD concentration of $9175 \mathrm{mg} \mathrm{L}^{-1}$. The average $\mathrm{NH}_{4}^{+}-\mathrm{N}$ concentration was $4540 \mathrm{mg} \mathrm{L}^{-1}$ while the concentrations of nitrite and nitrate in landfill leachate were below the detection limit of IC $\left(0.125 \mathrm{mg} \mathrm{L}^{-1}\right)$. The $\mathrm{pH}$ of the leachate sample was 7.94, which corresponded to an alkaline environment at the methanogenic phase of decomposition (Greenman et al., 2009). The conductivity was high at $28.1 \mathrm{mS} \mathrm{cm}^{-1}$ due to the high levels of inorganic

Table 1

Chemical characteristics of the landfill leachate used in this study.

\begin{tabular}{lll}
\hline Parameters & Values & Unit \\
\hline $\mathrm{pH}$ & 7.94 & \\
Conductivity & 28.1 & $\mathrm{mS} \mathrm{cm}^{-1}$ \\
COD & 9175 & $\mathrm{mg} \mathrm{L}^{-1}$ \\
$\mathrm{NH} 4^{-}-\mathrm{N}$ & 4540 & $\mathrm{mg} \mathrm{L}^{-1}$ \\
$\mathrm{Na}$ & 3342 & $\mathrm{mg} \mathrm{L}^{-1}$ \\
$\mathrm{~K}$ & 1299 & $\mathrm{mg} \mathrm{L}^{-1}$ \\
$\mathrm{Cl}$ & 5184 & $\mathrm{mg} \mathrm{L}^{-1}$ \\
$\mathrm{Mg}$ & 130.8 & $\mathrm{mg} \mathrm{L}^{-1}$ \\
$\mathrm{Si}$ & 60.9 & $\mathrm{mg} \mathrm{L}^{-1}$ \\
$\mathrm{P}$ & 16.4 & $\mathrm{mg} \mathrm{L}^{-1}$ \\
$\mathrm{Ca}$ & 72.5 & $\mathrm{mg} \mathrm{L}^{-1}$ \\
$\mathrm{Fe}$ & 23.8 & $\mathrm{mg} \mathrm{L}^{-1}$ \\
$\mathrm{Cu}$ & 0.8 & $\mathrm{mg} \mathrm{L}^{-1}$ \\
$\mathrm{Ni}$ & 0.2 & $\mathrm{mg} \mathrm{L}^{-1}$ \\
$\mathrm{Zn}$ & 0.7 & $\mathrm{mg} \mathrm{L}^{-1}$ \\
\hline
\end{tabular}

ions in the samples $\left(\mathrm{Na}^{+}, \mathrm{Cl}^{-}, \mathrm{Mg}^{2+}\right.$ etc. $)$. A variety of heavy metals ( $\mathrm{Cu}, \mathrm{Zn}, \mathrm{Ni}, \mathrm{Sr}, \mathrm{Mo}, \mathrm{Co}$, etc.) were also detected though at low concentrations. The leachate showed a dark brown-reddish color, which may be attributed to the presence of dissolved organic matter (e.g., humic acid and fulvic acid) (Baun and Christensen, 2004; Shouliang et al., 2008).

\subsection{Measurement and analysis}

The voltage across the external resistance in the MEC was recorded every $2 \mathrm{~min}$ by a digital multimeter (2700, Keithley Instruments Inc., Cleveland, $\mathrm{OH}, \mathrm{USA}$ ). The $\mathrm{pH}$ of the liquid stream was measured by a benchtop pH meter (Oakton Instruments, Vernon Hills, IL, USA). Conductivity was measured with a benchtop conductivity meter (Mettler-Toledo, Columbus, OH, USA). The COD concentration was measured using a colorimeter (Hach DR/890, Hach Company, Loveland, CO, USA). The concentration of ammonium was measured using an ISE meter (Accumet AB250, Fisher Scientific, Pittsburgh, PA, USA). Ion concentrations were quantified by using ion chromatography (Dionex LC20 ion chromatograph, Sunnyvale, CA, USA) equipped with an ED40 eletrochemical detector and inductively coupled plasma - mass spectrometry (Thermo Electron X-Series ICPMS, Waltham, MA, USA). The concentration of $\mathrm{CO}_{2}$ in the MEC outlet gas was quantified by a Shimadzu GC-14A gas chromatograph equipped with a thermal conductivity meter (TCD). The analysis of electrochemical impedance spectroscopy (EIS) of the FO membrane was conducted with a potentiostat (Reference 600, Gamry Instruments, Warminster, PA, USA) according to a previous study (Ge et al., 2013). The efficiency of organic-to-electricity was expressed by Coulombic recovery (CR) and Coulombic efficiency (CE), calculated as (Ge et al., 2013):

$$
\begin{aligned}
& C R=\frac{Q_{\text {output }}}{Q_{\text {input }-t}}=\frac{\sum I(A) t(s)}{96485\left(\frac{\mathrm{C}}{\text { mol e }^{-}}\right) \times C O D_{\text {total }}(\mathrm{mol}) \times 4\left(\frac{\text { mol e}^{-}}{\text {mol o }_{2}}\right)} \\
& C E=\frac{Q_{\text {output }}}{Q_{\text {input }}}=\frac{\sum I(A) t(s)}{96485\left(\frac{\mathrm{C}}{\text { mol e }^{-}}\right) \times C O D_{\text {removed }}(\mathrm{mol}) \times 4\left(\frac{\text { mol e}^{-}}{\text {mol }_{2}}\right)}
\end{aligned}
$$


where $Q_{\text {output }}$ is the produced charge, $Q_{\text {input- } t}$ is the total charge available in the added organic compounds, $Q_{\text {input }}$ is the total charge available in the removed organic compounds, $I$ is electric current and $t$ is the time. $C O D_{\text {total }}$ is the total COD in the anolyte in the period of time $t$, and calculated based on the input COD concentration and the remaining COD from the previous cycle. $C O D_{\text {removed }}$ is the removed COD within time $t$.

\section{Results and discussion}

\subsection{MEC performance}

The MEC performance was evaluated with the leachate sample under two modes, aeration in the cathode (oxygen reduction) and no aeration (hydrogen evolution). In the presence of aeration, oxygen would act as an electron acceptor and the air flow in the cathode compartment could also promote the stripping of ammonia out of the catholyte. In the absence of aeration, protons could be reduced to hydrogen gas. Both reactions can accumulate hydroxyl ions and thus elevate the $\mathrm{pH}$, which would facilitate the conversion of ammonium ion to ammonia gas.

Electricity generation in the MEC exhibited similar performance regardless of aeration (Fig. 2A). The maximum current density with aeration was $0.72 \pm 0.06 \mathrm{~A} \mathrm{~m}^{-2}$, similar to $0.70 \pm 0.12 \mathrm{~A} \mathrm{~m}^{-2}$ in the absence of aeration $(p>0.05)$. The MEC with aeration generated the total coulomb of $4274 \pm 500 \mathrm{C}$ in each batch cycle, which is not significantly different from $3791 \pm 583 \mathrm{C}$ in the absence of aeration $(p>0.05)$. The current generation was relatively stable under both modes but the COD concentration in the MEC effluent increased and thus the COD removal efficiency decreased with time. With aeration, the effluent COD was $4440 \mathrm{mg} \mathrm{L}^{-1}$ from the first batch and gradually increased to $5910 \mathrm{mg} \mathrm{L}^{-1}$ after 6 batches. Likewise, the effluent COD increased from 4440 to $8610 \mathrm{mg} \mathrm{L}^{-1}$ after 5 batches without aeration. This suggests that microbial ability of organic degradation was possibly impaired during operation, likely related to the accumulation of salt ions that will be discussed in the following section. Although the Coulombic efficiency increased from $29.87 \%$ to $46.89 \%$ (aeration) or from $37.61 \%$ to $110.40 \%$ (no aeration), mostly because of the amount of the removed COD decreased, the Coulombic recovery of the MEC was fairly stable at $15.45 \pm 1.80 \%$ (aeration) or $13.70 \pm 2.11 \%$ (no aeration) (Fig. 2B).

The $\mathrm{pH}$ of the MEC anode effluent was around 7, indicating that the landfill leachate had high buffering capacity. The catholyte $\mathrm{pH}$ remained stable around 10 in both operation modes. The conductivity of both the anolyte and the catholyte increased with operation (Fig. 2C), because of different reasons: the anolyte conductivity increased probably due to the accumulation of ions, while the catholyte conductivity increased because of the ion transportation from the anolyte across the CEM.

The MEC effectively decreased the concentration of ammonium in the leachate. When aeration was applied, the anode effluent contained ammonium nitrogen of $1012 \pm 109 \mathrm{mg} \mathrm{L}^{-1}$ (Fig. 3A) representing a removal efficiency of $65.7 \pm 9.1 \%$. Meanwhile, the catholyte had an ammonium concentration of $611 \pm 66 \mathrm{mg} \mathrm{L}^{-1}$, resulting from ammonium migration from the anolyte. The stripped ammonia was collected in the absorption bottle, in which the ammonium concentration increased gradually to $0.77 \mathrm{~mol} \mathrm{~L}^{-1}$ after 6 batch cycles. When there was no aeration (the solutions in both anode and cathode compartments were refilled with new solutions before the test), it was observed that the ammonium concentration in both compartments increased with operation batches: the ammonium concentration in the anode effluent increased from $889 \mathrm{mg} \mathrm{L}^{-1}$ (1st batch) to $1548 \mathrm{mg} \mathrm{L}^{-1}$ (5th batch) (Fig. 3B), corresponding to a decrease in ammonium removal
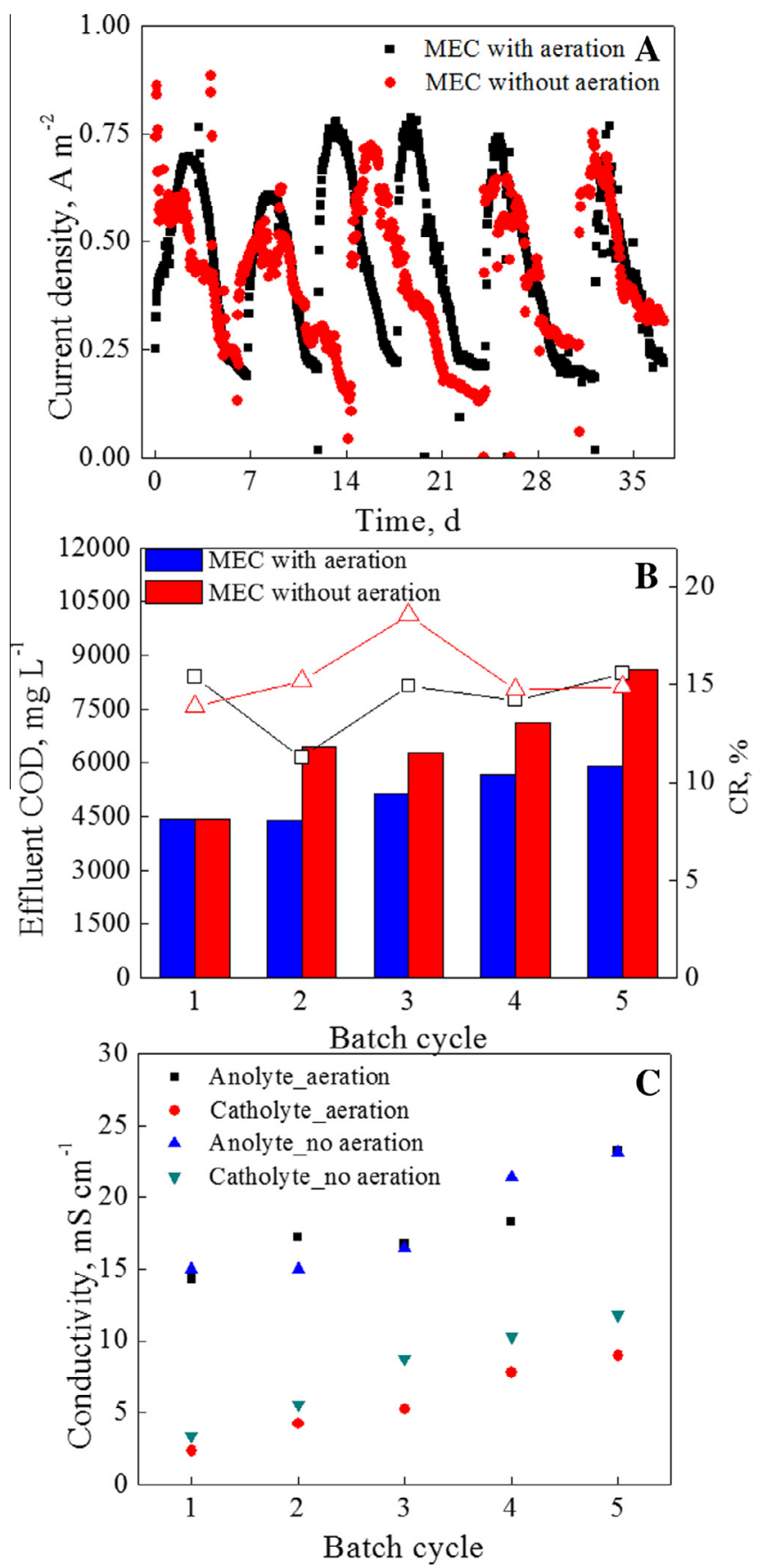

Fig. 2. The MEC performance fed with and without aeration: (A) current generation; (B) average effluent COD (columns) and Coulumbic recovery (CR) (symbolline); and (C) the MEC effluent conductivity.

efficiency from $68.1 \%$ to $47.2 \%$; the ammonium concentration in the catholyte increased from $840 \mathrm{mg} \mathrm{L}^{-1}$ (1st batch) to $8202 \mathrm{mg} \mathrm{L}^{-1}$ (5th batch). The inserts in Fig. $3 \mathrm{~A}$ and $\mathrm{B}$ indicated that the MEC with aeration achieved higher ammonium removal efficiency and more stable performance than that without aeration. In the absence of aeration, $88.9 \%$ of the input ammonium stayed in the solution (anode effluent and the catholyte) after 5 batch cycles. The anolyte $\mathrm{pH}$ was around 7 , which allowed ammonium nitrogen existing as $\mathrm{NH}_{4}^{+}$. In the catholyte, the $\mathrm{pH}$ was around 10 , and thus $85 \%$ of the ammonium nitrogen was present as ammonia $\left(\mathrm{NH}_{3}\right)$ (Koelliker and Kissel, 1988). The ammonia gas was dissolved in the catholyte due to its high solubility in aqueous solution. The membrane uptake for ammonium ion could be neglected because 

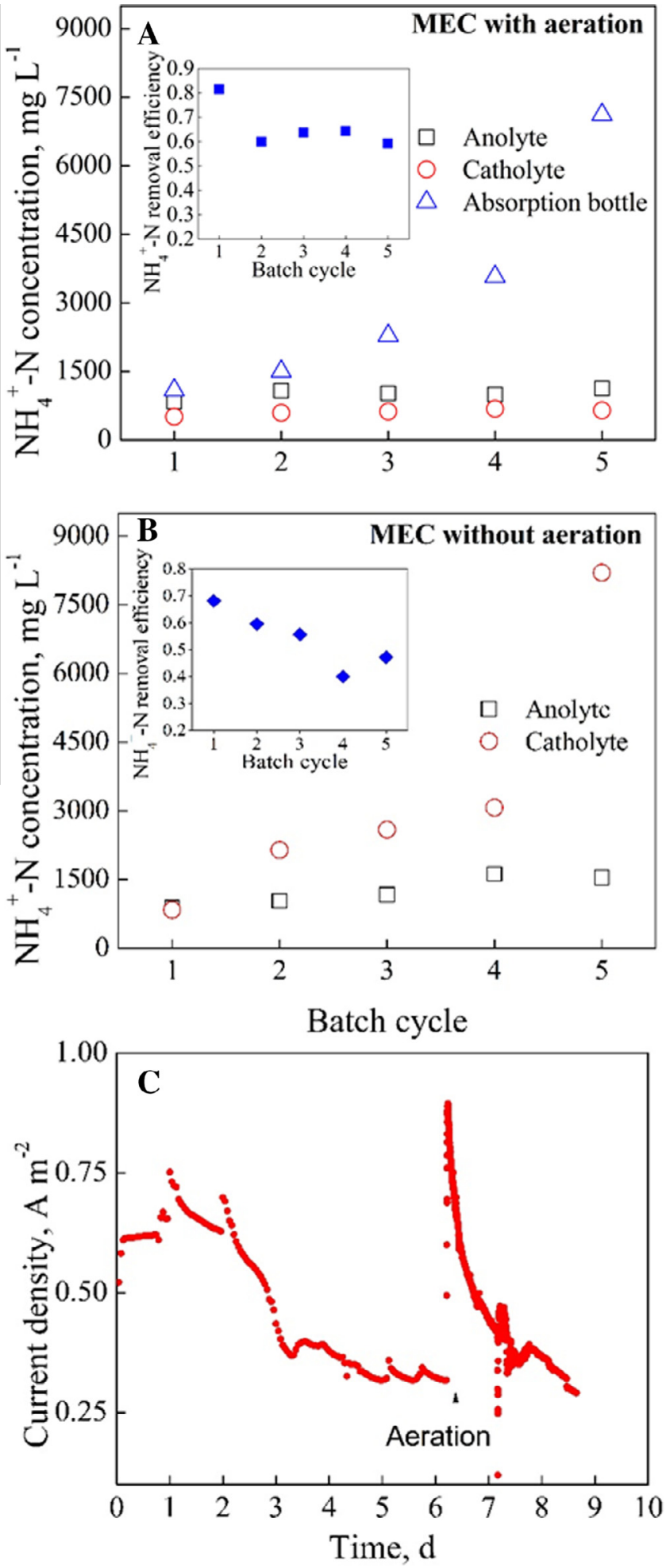

Fig. 3. Ammonium recovery in the MEC: (A) ammonium concentration with aeration; (B), (A) ammonium concentration without aeration; and (C) the current generation when aeration was put back to the MEC. The insets in (A) and (B) show the $\mathrm{NH}_{4}^{+}-\mathrm{N}$ removal efficiency $(\times 100 \%)$.

membrane sites were mostly occupied by $\mathrm{Na}^{+}$in the CEM. Although $11.1 \%$ of the ammonium nitrogen might have been converted to ammonia gas, the collection of ammonia gas was not successful in the absence of aeration, likely related to the low stripping effect. Even when the catholyte pH was adjusted to 12 or 12.6 at the beginning of the 4 th or the 5 th batch, the ammonium concentration in the catholyte was not obviously affected and the catholyte $\mathrm{pH}$ decreased to around 10 rapidly. After the 5th batch, the aeration was put back in the cathode chamber without replacement of either the anolyte or the catholyte: the current generation increased dramatically to $0.89 \mathrm{~A} \mathrm{~m}^{-2}$ and then decreased gradually to $0.31 \mathrm{~A} \mathrm{~m}^{-2}$ in 2 days (Fig. $3 \mathrm{C}$ ). With aeration, the cathode reaction changed from hydrogen evolution $(-0.41 \mathrm{~V}$ vs. SHE) to oxygen reduction $(0.82 \mathrm{~V}$ vs. $S H E)$, and the higher reaction potential for the reduction of oxygen increased the cell voltage, as well as the current generation. The aeration helped strip out the ammonia gas from the catholyte and thus facilitated further removal of ammonium from the anode.

In addition to ammonium, the compounds such as metal ions and organics could also migrate from the anolyte into the catholyte across the CEM. The concentrations of several major inorganic ions were monitored in the effluents from the 3rd and the 5th batches (Fig. 4). Sodium and potassium ions were the dominant cations in both electrolytes while chloride ions were the major anions. Other ions exhibited concentrations lower than $100 \mathrm{mg} \mathrm{L}^{-1}$. In the MEC with aeration, the removal efficiency for $\mathrm{K}^{+}, \mathrm{Na}^{+}$and $\mathrm{Cl}^{-}$was $16.1 \%, 44.7 \%$, and $49.1 \%$ in the 3 rd batch, and $9.4 \%, 25.2 \%$, and $40.4 \%$ in the 5 th batch, respectively. The lower removal efficiency in 5th batch was likely resulted from the ion accumulation in the catholyte, for example the $\mathrm{Na}^{+}$concentration rose from $449 \mathrm{mg} \mathrm{L}^{-1}$ in the 3rd batch to $950 \mathrm{mg} \mathrm{L}^{-1}$ in the 5 th batch, which created a concentration gradient against further migration. The removal efficiency of ions is determined by its concentration and mobility (Ping et al., 2015). The high concentration and high mobility of $\mathrm{K}^{+}, \mathrm{Na}^{+}$and $\mathrm{Cl}^{-}$led to stronger ion migration or diffusion across the membrane, resulting in a higher salinity in the catholyte, which could decrease the catholyte resistance and benefit the current generation. It was observed that more $\mathrm{K}^{+}$and $\mathrm{Na}^{+}$ions were transported across the CEM when there was no aeration, and this was probably related to the lower ammonium transportation under the same condition. Ion transport from the anolyte into the catholyte indicates that MECs may also remove other compounds than ammonium; however, because of nonvolatile feature of those ions, their accumulation in the cathode requires further treatment or periodic replacement of the concentrated solution.

After 6 batch cycles, the catholyte exhibited a dark yellow color but continued to be clear. The iron concentration in the catholyte was lower than $0.5 \mathrm{mg} \mathrm{L}^{-1}$ under both operation modes, which was insufficient to cause the observed color. It was found about $22 \%$ of the total organic carbon (TOC) was humic acid, which seems to be a plausible cause of the yellow color (Shouliang et al., 2008). However, after all the humic acid was precipitated out, the yellow color still existed. Therefore, the cause of the yellow color could also be related to other dissolved organic matter such as fulvic acid, and further investigation will be needed to understand the transportation of dissolved organic matter (DOM) across the CEM.

\subsection{FO performance}

Water recovery in the FO was examined with either the raw leachate or the MEC treated leachate, and the prepared ammonium bicarbonate was used as a draw solute. With $1 \mathrm{M}$ ammonium bicarbonate solution as the draw solution, the FO achieved a maximum water flux of $3.3 \pm 0.2 \mathrm{LMH}$ with the treated leachate (Fig. 5A), which decreased to $0.6 \pm 0.1 \mathrm{LMH}$ after 3.5 -h operation, and as a result, $26.2 \pm 1.3 \%$ of the treated leachate was extracted into the draw side. The water flux from the raw leachate was much lower, and the maximum water flux was $1.4 \mathrm{LMH}$ (Fig. 5A), resulting in only $12.3 \%$ of the leachate volume extracted into the draw chamber. The greater water flux from the treated leachate benefitted from a lower salt content than the raw $\left(17.4 \mathrm{vs} .28 .1 \mathrm{mS} \mathrm{cm}^{-1}\right)$, and thus a greater osmotic gradient was created. This indicated 

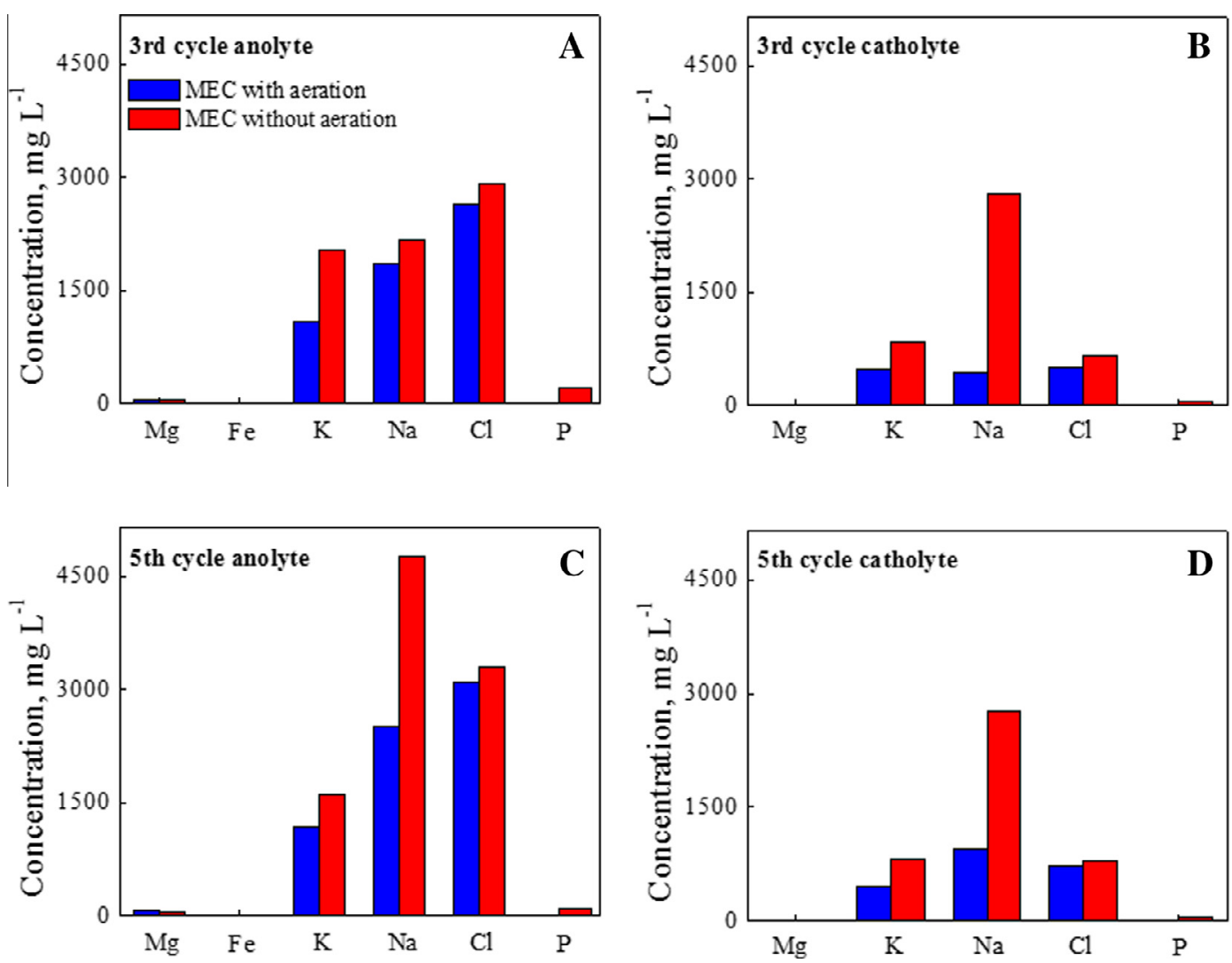

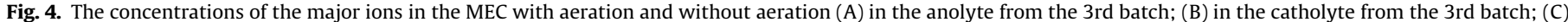
in the anolyte from the 5th batch; and (D) in the catholyte from the 5th batch.

that the MEC treatment could improve the FO performance. The FO treatment extracted water and also concentrated the ions in the feed solution (leachate). For example, the ammonium concentration in the feed solution increased from $1030 \pm 140$ to $7600 \pm 300 \mathrm{mg} \mathrm{L}^{-1}$. Reverse flux of ammonium from the draw side into the feed side could also increase the ammonium concentration. When the different concentrations of ammonium bicarbonate were used for draw solution ( $1 \mathrm{M}, 2 \mathrm{M}$ and $4 \mathrm{M})$, the reverse salt flux was $11.4 \pm 1.4, \quad 20.4 \pm 1.4, \quad 33.3 \pm 2.5 \mathrm{gMH}$, respectively (Fig. 5B). The reverse fluxed ammonium could be a concern for further treatment of the treated leachate, and it has been demonstrated that anammox may be used to remove the reverse-fluxed ammonium and thus alleviate the decline of water flux ( $\mathrm{Li}$ et al., 2015). When $2 \mathrm{M} \mathrm{NH}_{4} \mathrm{HCO}_{3}$ was used as draw solution, 51\% water recovery from the MEC effluent was achieved in 3.5-h operation. A higher $\mathrm{NH}_{4} \mathrm{HCO}_{3}$ concentration of $4 \mathrm{M}$ reduced the operating time to $2 \mathrm{~h}$ for achieving $50 \%$ water recovery, and a longer operating time of $3.5 \mathrm{~h}$ could extract $74 \%$ of the water in the leachate sample.

After 4-month experiment, the FO membrane was examined by measuring the water flux with DI water as the feed solution and $0.5 \mathrm{M} \mathrm{NH}_{4} \mathrm{HCO}_{3}$ as the draw solution. For comparison, a new FO membrane was tested, too. As shown in the insert of Fig. $5 \mathrm{C}$, the maximum water flux of the new FO membrane was 6.0 LMH, about 2.7 times higher than that of the used FO membrane (2.2 LMH), indicating that the membrane fouling decreased the water flux. To further understand the change in the FO membrane, the membrane resistance was measured by using EIS with $30 \mathrm{~g} \mathrm{~L}^{-1} \mathrm{NaCl}$ solution as electrolyte. Fig. 5C showed the impedance spectra for new and used FO membranes. The measured EIS can be fit by an equivalent circuit according to a previous study (Gao et al., 2013). The first intersection of the Nyquist plot and the $x$-axis represents the solution + membrane resistance. The new FO membrane had the solution + membrane resistance of $14.79 \Omega$, slightly lower than $16.30 \Omega$ from the used FO membrane. Because the bulk solution (without FO membrane) had a solution resistance of $13.50 \Omega$, the membrane resistance could be estimated as $1.29 \Omega$ for the new FO membrane or $2.80 \Omega$ for the used FO membrane, and the increase in membrane resistance of the used FO membrane was due to fouling. The charge transfer resistance was $1.75 \Omega$ for new FO membrane and $1.18 \Omega$ for used FO membrane, indicating that ion (e.g., $\mathrm{Na}^{+}$) flux could increase when $\mathrm{FO}$ membrane is subjected to fouling (She et al., 2012).

\subsection{The MEC-FO system}

When the MEC was linked to the FO unit, the MEC anode effluent (treated leachate) was fed to the FO feed side and the concentrated feed solution was returned to the MEC anode mixed with raw leachate $(\sim 1: 1)$. This mixture had a COD of $11200 \pm 1400 \mathrm{mg} \mathrm{L}^{-1}$. As shown in Fig. 6A, the maximum current density decreased from $0.76 \mathrm{~A} \mathrm{~m}^{-2}$ to $0.41 \mathrm{~A} \mathrm{~m}^{-2}$ after 3 batch cycles. In addition, the COD removal efficiency decreased from $40.3 \%$ to $32.9 \%$, probably related to the salt accumulation in the anolyte: after 3 batches, the $\mathrm{Na}, \mathrm{Cl}$ and $\mathrm{K}$ concentrations in the MEC anolyte reached $5080 \mathrm{mg} \mathrm{L}^{-1}, 3067 \mathrm{mg} \mathrm{L}^{-1}$, and $1846 \mathrm{mg} \mathrm{L}^{-1}$, respectively. The high salt concentration (higher than $100 \mathrm{mM}$ ) could adversely affect the physiology of anaerobic microbial consortia (Lefebvre et al., 2012; Rousseau et al., 2013).

The MEC removed $63.7 \pm 6.6 \%$ of ammonium in the mixture, and an ammonium mass balance suggested that $36.2 \pm 6.6 \%$ of ammonium stayed in the anolyte, $9.9 \pm 2.0 \%$ was present in the catholyte and $53.8 \pm 5.5 \%$ was stripped out as ammonia gas. The ammonium concentration in anolyte effluent increased from $1400 \mathrm{mg} \mathrm{L}^{-1}$ to $2900 \mathrm{mg} \mathrm{L}^{-1}$ during 3 batch cycles, which was due to high 

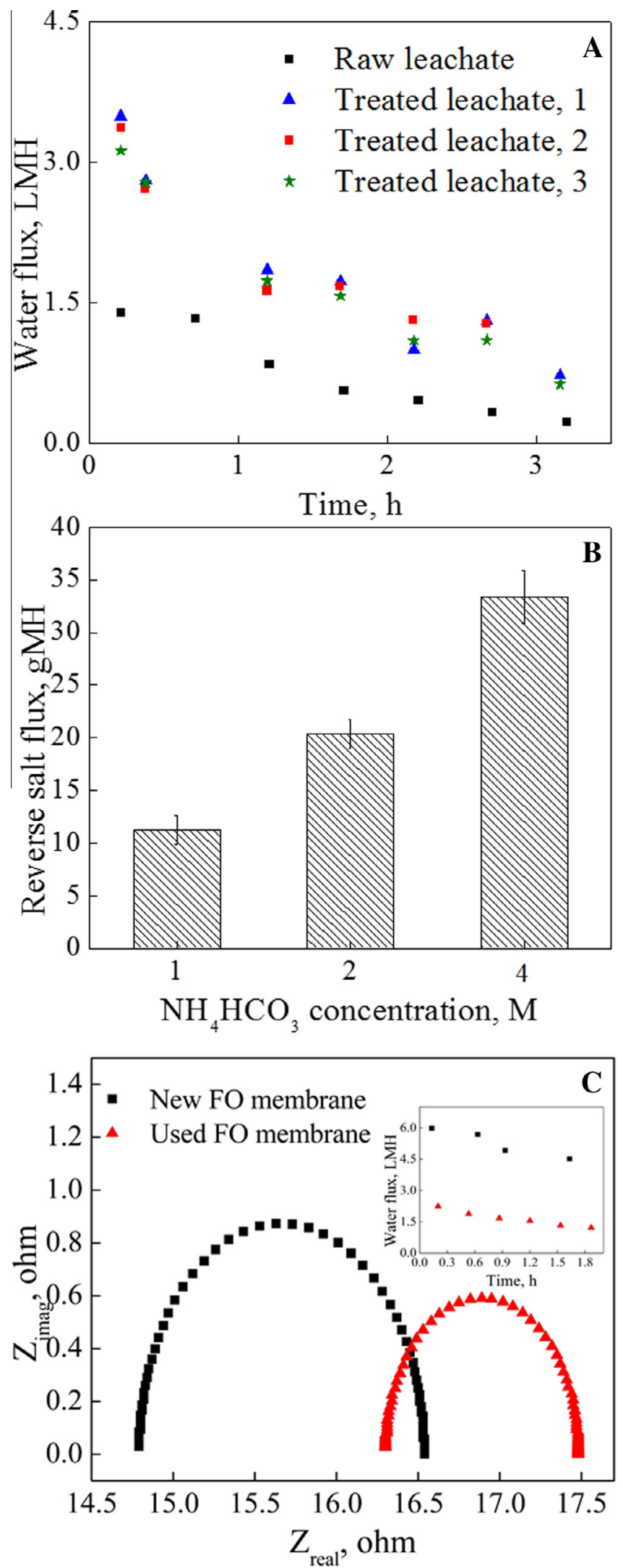

Fig. 5. The FO performance fed with the treated leachate: (A) water flux with $1 \mathrm{M}$ $\mathrm{NH}_{4} \mathrm{HCO}_{3}$ as draw solution; (B) reverse salt flux with different $\mathrm{NH}_{4} \mathrm{HCO}_{3}$ concentrations; and (C) EIS for new and used FO membranes. The inset in (C) shows the water flux with $0.5 \mathrm{M} \mathrm{NH}_{4} \mathrm{HCO}_{3}$ as draw solution for new and used $\mathrm{FO}$ membranes.
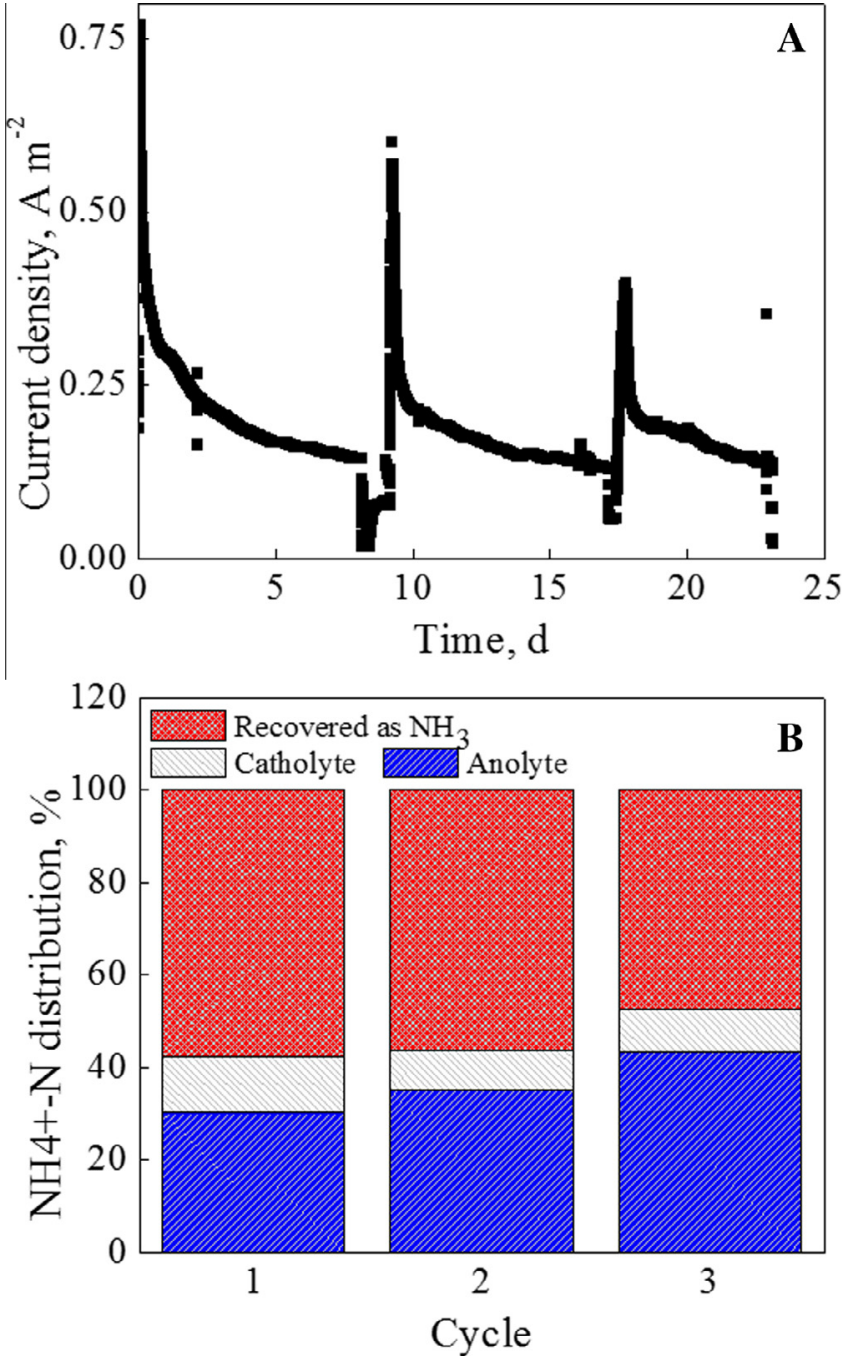

Fig. 6. The MEC-FO system performance: (A) current generation; and (B) $\mathrm{NH}_{4}^{+}-\mathrm{N}$ distribution during 3 batch cycles.

ammonium input from the FO returning solution. During the FO process, a large amount of ammonium moved across the FO membrane from the draw side into the feed side due to reverse salt flux. The ammonium concentration in the concentrated feed solution was $7800 \pm 1600 \mathrm{mg} \mathrm{L}^{-1}$, in which $57.8 \pm 2.3 \%$ was attributed to the reverse salt flux. After the mix with raw leachate, the ammonium concentration decreased to $6100 \pm 800 \mathrm{mg} \mathrm{L}^{-1}$. The concentration of $\mathrm{Na}^{+}, \mathrm{K}^{+}$and $\mathrm{Cl}^{-}$in the diluted draw solution was 101 , 49 and $93 \mathrm{mg} \mathrm{L}^{-1}$, respectively, representing salt rejection of 95.8\%, 94.6\% and $97.8 \%$. No COD was detected in the FO draw effluent.

Theoretical analysis indicates that in the MEC with aeration, the energy input was $5.0 \mathrm{kWh} \mathrm{m}^{-3}$ treated water $\left(1.3 \mathrm{kWh} \mathrm{kg}^{-1} \mathrm{COD}\right.$, or $8.5 \mathrm{kWh} \mathrm{kg}^{-1} \mathrm{~N}$ ), among which $64.4 \%$ was consumed by the external power supply, $13.0 \%$ was due to the aeration in the cathode, and $22.6 \%$ was consumed by the anolyte recirculation. In the MEC without aeration, the energy input was $4.7 \mathrm{kWh} \mathrm{m}^{-3}$ treated water $\left(1.5 \mathrm{kWh} \mathrm{kg}^{-1} \mathrm{COD}\right.$, or $\left.8.4 \mathrm{kWh} \mathrm{kg}^{-1} \mathrm{~N}\right)$. The hydrogen gas was not successfully collected in the MEC without aeration. In the FO process, the energy input was $0.1 \mathrm{kWh} \mathrm{m}^{-3}$ treated water, which was much lower than that of the MEC. Because the external power is the major energy consumer, future studies will 
investigate the approach using MFCs for treatment, although lower current generation would be expected.

The MEC-FO system can be effective for organic removal, nutrient recovery and clean water recovery from leachate. However, there are challenges when the concentrated solution from the FO is returned to the MEC anode. This returned solution increases the concentration of both ions and recalcitrant organic compounds, which make it difficult in the successive treatment. A potential solution for addressing this issue is to introduce pretreatment before the MEC treatment. A proper pretreatment method can improve biodegradability of leachate and thus current generation in the MEC. Higher current output will promote ammonium transport and increase ammonium recovery. More ions will also be moved into the cathode of the MEC, thereby alleviating the adverse effects of ion concentrating in the FO and its returning solution. It should be noted that, because ions other than ammonium will be only concentrating in the solution (either the anolyte or the catholyte), periodical replacement of the concentrating solution will be necessary, and the frequency of such replacement will need to be determined experimentally.

\section{Conclusions}

This study has furthered the development of an MEC-FO system through examining its performance with actual landfill leachate. The system could effectively generate electricity and recover ammonia. The recovered ammonia was successfully used as a draw solute in the following FO process for water recovery. Aeration in the MEC cathode was found to be necessary for ammonia collection. More water could be covered from the MEC treated leachate than from the raw leachate, because of the reduced salinity. This system has a potential for resource recovery from wastes, and will be investigated for further improvement through pretreatment.

\section{Acknowledgements}

This study was supported by a grant from Environmental Research and Education Foundation. The authors would like to thank Ankit Pathak (Virginia Tech) for providing landfill leachate, Peppers Ferry Regional Wastewater Treatment Plant for providing inocula and Jeffery Parks (Virginia Tech) for helping with inductively coupled plasma - mass spectrometry measurement.

\section{References}

Baun, D.L., Christensen, T.H., 2004. Speciation of heavy metals in landfill leachate: a review. Waste Manag. Res. 22, 3-23.

Cath, T.Y., Childress, A.E., Elimelech, M., 2006. Forward osmosis: principles, applications, and recent developments. J. Membrane Sci. 281, 70-87.

Damiano, L., Jambeck, J.R., Ringelberg, D.B., 2014. Municipal solid waste landfill leachate treatment and electricity production using microbial fuel cells. Appl. Biochem. Biotechnol. 173, 472-485.

Foo, K., Hameed, B., 2009. An overview of landfill leachate treatment via activated carbon adsorption process. J. Hazard. Mater. 171, 54-60.

Gálvez, A., Greenman, J., Ieropoulos, I., 2009. Landfill leachate treatment with microbial fuel cells; scale-up through plurality. Bioresour. Technol. 100, 50855091.

Ganesh, K., Jambeck, J.R., 2013. Treatment of landfill leachate using microbial fuel cells: alternative anodes and semi-continuous operation. Bioresour. Technol. 139, 383-387.

Gao, Y. Li, W., Lay, W.C., Coster, H.G.,Fane, A.G., Tang C.Y, 2013. Characterization of forward osmosis membranes by electrochemical impedance spectroscopy. Desalination 312, 45-51.
Ge, Z., Ping, Q., Xiao, L., He, Z., 2013. Reducing effluent discharge and recovering bioenergy in an osmotic microbial fuel cell treating domestic wastewater. Desalination 312, 52-59.

Gotvajn, A.Ž., Tišler, T., Zagorc-Končan, J., 2009. Comparison of different treatment strategies for industrial landfill leachate. J. Hazard. Mater. 162, 1446-1456.

Greenman, J., Gálvez, A., Giusti, L., Ieropoulos, I., 2009. Electricity from landfill leachate using microbial fuel cells: comparison with a biological aerated filter. Enzyme Microb. Technol. 44, 112-119.

Hoornweg, D., Bhada-Tata, P. 2012. What a waste: a global review of solid waste management.

Koelliker, J., Kissel, D. 1988. Chemical equilibria affecting ammonia volatilization. In Ammonia volatilization from urea fertilizers. pp. 37-52.

Kulikowska, D., Klimiuk, E., 2008. The effect of landfill age on municipal leachate composition. Bioresour. Technol. 99, 5981-5985.

Kurniawan, T.A., Lo, W.H., Chan, G.Y., 2006. Physico-chemical treatments for removal of recalcitrant contaminants from landfill leachate. J. Hazard. Mater. 129, 80-100.

Lefebvre, O., Tan, Z., Kharkwal, S., Ng, H.Y., 2012. Effect of increasing anodic NaCl concentration on microbial fuel cell performance. Bioresour. Technol. 112, 336340.

Li, X., Lu, Y., He, Z., 2015. Removal of reverse-fluxed ammonium by anammox in a forward osmosis system using ammonium bicarbonate as a draw solute. J. Membr. Sci. 495, 424-430.

Liang, Z., Liu, J., 2008. Landfill leachate treatment with a novel process: anaerobic ammonium oxidation (Anammox) combined with soil infiltration system. J. Hazard. Mater. 151, 202-212.

Mahmoud, M., Parameswaran, P., Torres, C.I., Rittmann, B.E., 2014. Fermentation pre-treatment of landfill leachate for enhanced electron recovery in a microbial electrolysis cell. Bioresour. Technol. 151, 151-158.

Pant, D., Van Bogaert, G., Diels, L., Vanbroekhoven, K., 2010. A review of the substrates used in microbial fuel cells (MFCs) for sustainable energy production. Bioresour. Technol. 101, 1533-1543.

Ping, Q., Huang, Z, Dosoretz, C. He, Z, 2015. Integrated experimental investigation and mathematical modeling of brackish water desalination and wastewater treatment in microbial desalination cells. Water Res. 77, 13-23.

Puig, S., Serra, M., Coma, M., Cabré, M., Balaguer, M.D., Colprim, J., 2011. Microbia fuel cell application in landfill leachate treatment. J. Hazard. Mater. 185, 763767.

Qin, M., He, Z., 2014. Self-supplied ammonium bicarbonate draw solute for achieving wastewater treatment and recovery in a microbial electrolysis cellforward osmosis-coupled system. Environ. Sci. Technol. Lett. 1, 437-441.

Renou, S., Givaudan, J., Poulain, S., Dirassouyan, F., Moulin, P., 2008. Landfill leachate treatment: review and opportunity. J. Hazard. Mater. 150, 468-493.

Rousseau, R., Dominguez-Benetton, X., Délia, M.L., Bergel, A., 2013. Microbial bioanodes with high salinity tolerance for microbial fuel cells and microbial electrolysis cells. Electrochem. Commun. 33, 1-4.

Ruscalleda, M., López, H., Ganigué, R., Puig, S., Balaguer, M., Colprim, J., 2008 Heterotrophic denitrification on granular anammox SBR treating urban landfill leachate. Water Sci. Technol. 58, 1749-1755.

She, Q., Jin, X., Li, Q., Tang, C.Y., 2012. Relating reverse and forward solute diffusion to membrane fouling in osmotically driven membrane processes. Water Res. 46 , 2478-2486.

Shouliang, H., Beidou, X., Haichan, Y., Liansheng, H., Shilei, F., Hongliang, L., 2008 Characteristics of dissolved organic matter (DOM) in leachate with different landfill ages. J. Environ. Sci. 20, 492-498.

Teng, S.X., Tong, Z.H., Li, W.W., Wang, S.G., Sheng, G.P., Shi, X.Y., Liu, X.W., Yu, H.Q. 2010. Electricity generation from mixed volatile fatty acids using microbial fuel cells. Appl. Microbiol. Biotechnol. 87, 2365-2372.

Wang, H., Ren, Z.J., 2013. A comprehensive review of microbial electrochemical systems as a platform technology. Biotechnol. Adv. 31, 1796-1807.

Wang, K.Y., Ong, R.C., Chung, T.-S., 2010. Double-skinned forward osmosis membranes for reducing internal concentration polarization within the porous sublayer. Ind. Eng. Chem. Res. 49, 4824-4831.

Wu, D., Wang, T., Huang, X., Dolfing, J., Xie, B., 2015. Perspective of harnessing energy from landfill leachate via microbial fuel cells: novel biofuels and electrogenic physiologies. Appl. Microbiol. Biotechnol. 99, 7827-7836.

Yossan, S., Xiao, L., Prasertsan, P., He, Z., 2013. Hydrogen production in microbial electrolysis cells: choice of catholyte. Int. J. Hydrogen Energy 38, 9619-9624.

Zhang, F., He, Z., 2013. A cooperative microbial fuel cell system for waste treatment and energy recovery. Environ. Technol. 34, 1905-1913.

Zhang, F., Jacobson, K.S., Torres, P., He, Z., 2010. Effects of anolyte recirculation rates and catholytes on electricity generation in a litre-scale upflow microbial fue cell. Energy Environ. Sci. 3, 1347-1352.

Zhang, F., Li, J., He, Z., 2014. A new method for nutrients removal and recovery from wastewater using a bioelectrochemical system. Bioresour. Technol. 166, 630634. 